\title{
Gedung Seni Dan Budaya Banyumas Dengan Pendekatan lokalitas Di PURWOKERTo
}

\author{
Kirana Wahyu Kinanti, Titis S. Pitana, Sri Yuliani \\ Program Studi Arsitektur \\ Jurusan Arsitektur Fakultas Teknik \\ Universitas Sebelas Maret Surakarta \\ Email : kiranawahyu26@gmail.com
}

\begin{abstract}
:
Design and planningof Banyumas art and cultural building are based on the need of art and cultural facility in Banyumas Regency. There have been many art andcultural facilities in Banyumas, but no one are spesifically design for art and cultural activity. Because of these reason, those cultural faciliies can not be used efisienly. Art and cultural building, whichis located in Purwokerto City, also needs to have a touch of Banyumas Cultural nuance as part of its integrated design. The goal of Art and Cultural Building designing and planing is get an Art and Cultural Building with Banyumasn Nuance by using Locality Prespective as an Approach. This locality prespective will be used along the design and planing and can be seen at groundplan, siteplan, massing, Landscape, and structure. The result is a design of art and cultural building with many facilities such as artist and cultural observer secretariat, auditorium, galery, amphitheatre, pendhapa, office building, and mousque.
\end{abstract}

Keywords: Art centre, Culture, Defined Cultural of Banyumas, Locality

\section{PENDAhUluAN}

Seni dan budaya Banyumas merupakan warisan budaya yang berupa kebudayaan tradisional yang didukung masyarakatnya. Budaya Banyumas ditata oleh masyarakatnya menjadi sesuatu yang harmonis dan khas.

Lokalitas dalam kajian ini adalah pendekatan atau sudut pandang filosofis. Kata lokalitas berasal dari kata locality yang berarti tempat. Oleh karena itu lokalitas dapat diartikan sebagai sesuatu yang spesifik atau khas dari suatu daerah tertentu.

Lokalitas dalam arsitektur dapat dimaknai sebagai upaya untuk tetap bertaut dengan kondisi setempat dengan mencari potensi yang spesifik. Potensi tersebut bisa terkait dengan tradisi, memori masa lalu, teknologi, material atau yang lain. Lokalitas tidak melawan globalisasi namun menyandingkan antara global dan lokal. Pendekatan lokalitas diharapkan dapat memberikan nuansa Banyumasan.

Kebutuhan akan adanya Gedung Seni dan Budaya terlihat dari beberapa aspek. Aspek tersebut terbagi menjadi beberapa faktor, faktor-faktor tersebut adalah sebagai berikut.

\subsection{Kesenian dan Kebudayaan Banyumas Merupakan Sub Kultur Jawa}

Wilayah Banyumas adalah perbatasan dari dua kebudayaan besar yaitu Sunda dan Jawa (lihat Gambar 1). Oleh karena itu terjadi akulturasi kebudayaan dari Jawa dan Sunda yang dikenal dengan budaya Banyumas (Koderi:1991). Banyumas sebagai wilayah budaya, memiliki keberagaman kesenian. Di teater ditemukan munthiet, jemblung, begalan, kethoprak Banyumas dan wayang kulit Banyumas. Di seni tari terdapat lengger, aplang, dareng, buncis, ebeg, sintren dan $a k s i$ muda. Di seni karawitan (musik) dijumpai kaster, bongkel, krumpyung, calung, terbang jawa, rodad, cak genjring dan karawitan.

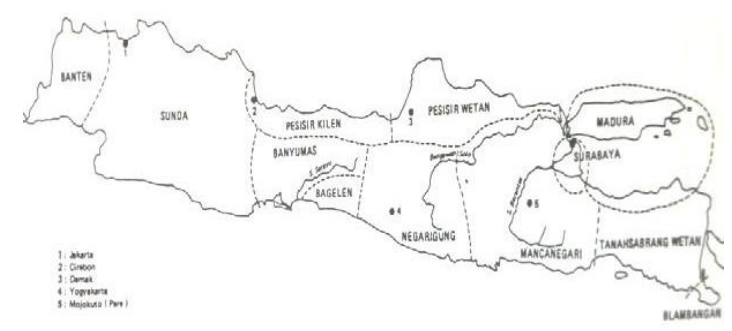

Gambar 1 Peta Kebudayaan Jawa (Sumber : Koentjaraningrat:1984) 


\subsection{Kegiatan Seni dan Budaya Masyarakat Banyumas}

Masyarakat Banyumas telah menjadikan seni dan budaya sebagai begian dari hidup mereka. Berdasarkan data yang diperoleh dari Dinas Pemuda Olahraga dan Pariwisata terdapat lebih dari $50 \%$ di 27 kecamatan di Kabupaten Banyumas memiliki sanggar seni (lihat Tabel 1).

Tabel 1 Jumlah Sanggar Seni dan Budaya di Tingkat Kecamatan di Banyumas

\begin{tabular}{llll}
\hline \multicolumn{1}{c}{ Kec. } & Jml & \multicolumn{1}{c}{ Kec. } & Jml \\
\hline Lumbir & 30 & Sokaraja & 18 \\
Wangon & 10 & Kalibagor & 3 \\
Gumelar & 25 & Banyumas & 22 \\
Ajibarang & 25 & Kebasen & 3 \\
Baturaden & 11 & Tambak & 3 \\
Kembaran & 8 & Sumpiuh & 3 \\
Purwokerto & 5 & Kemranjen & 2 \\
Barat & & & \\
Sumbang & 2 & Somagede & 7
\end{tabular}

Sumber : Dinas Pemuda, Olahraga dan

Pariwisata:2014

\subsection{Fasilitas Seni dan Budaya di Banyumas}

Terdapat 5 fasilitas untuk kegiatan seni dan budaya di Kabupaten Banyumas, yakni sebagai berikut.

a. Aula RRI Purwokerto, aula RRI Purwokerto sering digunakan untuk pagelaran wayang.

b. Gedung Kesenian Soetedja, Pada awal tahun 80-an gedung ini merupakan sentra kegiatan seni dan budaya, banyak seniman dan budayawan yang sering berkumpul dan berdiskusi mengenai pekembangan seni dan budaya Banyumas.

c. Lokawisata Baturaden, Lokawisata Baturaden merupakan sebuah objek wisata yang dilengkapi dengan panggung terbuka. Panggung terbuka inilah yang sering digunakan untuk pergelaran seni. d. GOR Satria, lapangan GOR Satria sering digunakan untuk konser terbuka.

e. Gedung BPD, gedung ini sering digunakan untuk pameran seni lukis.

Dari beberapa fasilitas di atas tidak ada fasilitas berkesenian dan berkebudayaan yang direncanakan untuk kegiatan berkesenian dan berkebudayaan. Fasilitas-fasilitas tersebut merupakan bangunan yang beralih fungsi.

\subsection{Faktor lain yang mendukung}

Pemerintah sejak 5 tahun terakhir melaksanakan program yang bertujuan membanyumaskan kembali Banyumas. Beberapa langkah yang telah diambil pemerintah antara lain pengunaan bahasa Jawa Banyumas pada hari tertentu disetiap minggu, menggunakan batik Banyumas sebagai salah satu seragam, pembentukan Sanggar Paseban Kamanjaya yang bergerak di bidang seni dan perencanaan revitalisasi kota lama Banyumas yang diawali dengan seminar revitalisasi kota lama Banyumas.

\section{METODE}

\subsection{Teknik Pengumpulan Data}

Kegiatan pengumpulan data dilakukan dengan penelitian lapangan dan studi literatur.

a. Penelitian lapangan dilakukan dengan melihat langsung objek bangunan ataupun bangunan lain yang dapat dijadikan referensi dalam perancangan. Teknik yang digunakan untuk penelitian lapangan adalah sebagai berikut.

1) Observasi terhadap objek yaitu Gedung Kesenian Soetedja dan Taman Budaya Surakarta. Observasi juga dilakukan terhadap rumah srotong yang ditemukan di daerah Banyumas.

2) Wawancara dilakukan kepada seniman, Dinas Pemuda, Olahraga dan Pariwisata, dan perwakilan organisasi kesenian yang ada di Banyumas. Kriteria narasumber adalah orang yang memiliki pengetahuan mendalam mengenai 
objek dan mendapatkan pendidikan setara dengan $\mathrm{S} 1$.

b. Studi literatur dilakukan melalui pencarian data dari buku-buku, jurnal dan sebagainya. Materi tersebut meliputi hal-hal :

1) buku-buku seni dan budaya Banyumas,

2) buku-buku mengenai lokalitas dan lokalitas Banyumas,

3) buku-buku yang terkait dengan fasilitas dan standar Gedung Seni dan Budaya,

4) rencana umum tata ruang wilayah Kabupaten Banyumas, dan

5) wacana dari jurnal maupun artikel yang mendukung.

\subsection{Analisis dan Sintesis}

Analisis dilakukan dengan melakukan kajian data dan informasi yang telah diperoleh dari penelitian lapangan di Banyumas dan studi literatur. Tahapan analisis ini terbagi menjadi tiga yaitu pemrograman fungsional, pemrograman performansi, dan pemrograman arsitektural. Hasil analisis, akan dirumuskan untuk mendapatkan konsepkonsep yang dibutuhkan, seperti konsep lokasi dan pengolahannya, konsep kegiatan dan peruangan, konsep tampilan masa, konsep struktur, konsep utilitas, konsep tata landscape dan konsep interior.

\subsection{Konsep}

Konsep didapatkan dari proses sintesis terhadap analisa-analisa pada data yang diperoleh. Konsep akan menjadi pedoman saat mendesain.

\section{ANALISIS}

Aspek lokalitas pada perencanaan Gedung Seni dan Budaya akan diterapkan pada hal-hal berikut ini.

\subsection{Konsep Pencapaian}

Kawasan dicapai dengan meletakkan titik pencapaian utama di utara dan selatan. Pertimbangan perletakkan ini adalah di sebelah utara terdapat Gunung Slamet dan disebelah setalan terdapat pantai. Perletakkan bukaan masuk dilakukan berdasarkan hitungan Jawa dengan sistem "empat sembilan" (lihat Gambar 2)

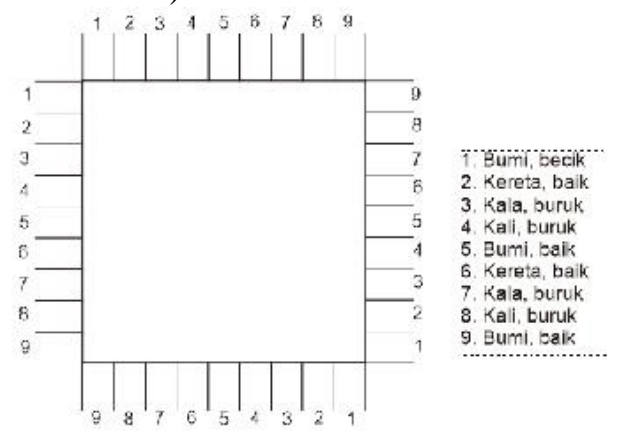

Gambar 2 Sistem Perhitungan Jawa
Sumber : Ismunandar:1993

Oleh karena itu akses masuk dari luar menuju tapak terbagi menjadi pintu masuk utama dan pintu samping (lihat Gambar 3).

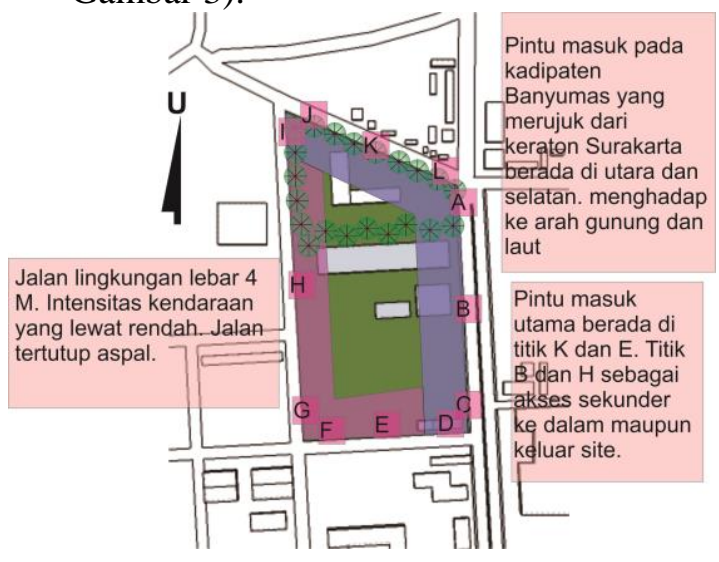

Gambar 3 Titik Perletakan Pintu Masuk ke Kawasan

\subsection{Konsep Pengguna Gedung Seni dan Budaya Banyumas}

a. Pengguna dan Jenis Kegiatan

Pengguna Gedung Seni dan Budaya Banyumas dapat dikelompokkan menjadi beberapa kelompok berikut.

1) Pengunjung.

2) Pemain dan penyelenggara pertunjukkan.

3) Seniman dan kurator.

4) Peserta dan instruktur sanggar.

5) Pengelola.

6) Organisasi seni dan budaya Banyumas.

Kelompok kegiatan dalam Gedung Seni dan Budaya dikelompokkan menjadi beberapa kelompok berikut. 
1) Kegiatan pelatihan meliputi pelatihan di sanggar, workshop, dan diskusi seni dan budaya.

2) Kegiatan pertunjukkan di dalam dan di luar ruangan.

3) Kegitan pameran

4) Kegiatan informasi dan pengelolaan.

5) Kegiatan servis dan pemeliharaan.

b. Konsep Kebutuhan Ruang

Kebutuhan ruang yang dibutuhkan pada Gedung Seni dan Budaya Banyumas terbagi menjadi beberapa kelompok, yaitu kelompok ruang pelatihan, pertunjukkan, pengelolaan, pameran dan organisasi seni (lihat Tabel 2).

Tabel 2 Kebutuhan Ruang

\begin{tabular}{ll}
\hline \multicolumn{1}{c}{$\begin{array}{c}\text { Kelompok } \\
\text { kegiatan }\end{array}$} & \multicolumn{1}{c}{ Ruang-ruang } \\
\hline $\begin{array}{l}\text { Kegiatan } \\
\text { pelatihan }\end{array}$ & $\begin{array}{l}\text { Sanggar seni, } \\
\text { Wisma seni, } \\
\text { Pendhapa }\end{array}$ \\
$\begin{array}{l}\text { Kegiatan } \\
\text { Pertunjukkan }\end{array}$ & $\begin{array}{l}\text { Ruang } \\
\text { pertunjukkan } \\
\text { Kegiatan } \\
\text { Pengelolaan }\end{array}$ \\
$\begin{array}{l}\text { Kegiatan } \\
\text { Pameran }\end{array}$ & $\begin{array}{l}\text { Galeri dan ruang } \\
\text { pameran }\end{array}$ \\
$\begin{array}{l}\text { Kegiatan } \\
\text { Organisasi }\end{array}$ & Ruang sekretariat \\
Kesenian & \\
\hline
\end{tabular}

\subsection{Konsep Program Ruang}

Kebutuhan luasan dan volume di Gedung Seni dan Budaya Banyumas diperhitungkan berdasarkan kegiatan yang dilakukan, furniture yang digunakan, citra ruangan yang diinginkan, dan besar alur sirkulasi. (lihat Tabel 3).

Tabel 3 Kebutuhan Luasan dan Volume

\begin{tabular}{ccc}
\hline Kelompok ruang & $\begin{array}{c}\text { Luas } \\
\left(\mathrm{m}^{2}\right)\end{array}$ & $\begin{array}{c}\text { Volume } \\
\left(\mathrm{m}^{3}\right)\end{array}$
\end{tabular}

\begin{tabular}{lll}
\hline Ruang Pelatihan & 1308,28 & 4803,08 \\
$\begin{array}{l}\text { Ruang } \\
\text { Pertunjukkan }\end{array}$ & 1314,5 & 4288,5 \\
$\begin{array}{l}\text { Ruang } \\
\text { Pengelolaan }\end{array}$ & 268 & 938 \\
\hline
\end{tabular}

\begin{tabular}{lll}
\hline Ruang Pameran & 416 & 2496 \\
$\begin{array}{l}\text { Ruang Organisasi } \\
\text { Seni }\end{array}$ & 284 & 994 \\
$\begin{array}{l}\text { Ruang penunjang } \\
\text { Luasan total }\end{array}$ & 4627 & 1481 \\
\hline
\end{tabular}

3.4 Konsep Bentuk Ruang

3.4.1 Ruang galeri dan pameran

Bentuk ruang menyesuaikan dengan kebutuhan ruang dari kesenian yang ada di Banyumas, bentuk kotak adalah bentuk umum yang digunakan di rumah srotong. Bentuk ini akan digunakan pada ruang galeri dan pertunjukkan indoor sedangkan pada pertunjukkan di luar ruangan menggunakan bentuk lingkaran. Hal ini dikarenakan masyarakat Banyumas sering menyaksikan pertunjukkan dengan melingkari penyaji. Perancangan ruang pamer memperhatikan sirkulasi ruang, sistem penyajian dan pencahayaan.

a. Sirkulasi,

Sirkulasi ruang pameran harus fleksibel dan dapat memberikan informasi pada pengunjung sehingga pengunjung dapat memahami dan mengapresiasi karya. Di rumah srotong penghuni dapat berjalan melingkar mengelilingi rumah. Oleh karena itu, sirkulasi melingkar dipilih untuk ruang pameran (lihat Gambar 4).

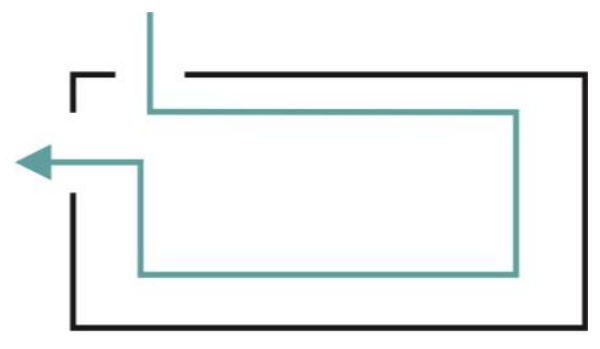

Gambar 4 Pola Sirkulasi Ruang
Pameran

b. Sistem penyajian

Karya pameran 2 dimensi dipamerkan dengan cara digantung, sedangkan karya 3 dimensi ditampilkan dengan mempertimbangkan personal space pengunjung. 
c. Pencahayaan

$\begin{array}{lrr}\text { Pencahayaan } & \text { di ruang } \\ \text { pameran } & \text { menggunakan }\end{array}$ pencahayaan buatan yang terbagi menjadi pencahayaan umum dan pecahayaan langsung ke arah karya seni.

d. Penghawaan
Penghawaan
pameran
pada ruang menggunakan penghawaan buatan. Pertimbangan penggunaan sistem ini adalah penghawaan buatan dapat diatur kelembabannya sehingga karya yang dipajang tidak mengalami kerusakan.

\subsubsection{Ruang pergelaran di dalam ruangan dan di luar ruangan}

Dalam perencanaan ruang pergelaran di dalam ruangan yang paling utama adalah kenyamanan visual dan kenyamanan audial penonton. Kenyamanan tersebut dapat diperoleh dengan bentuk ruang yang sesuai, sistem akustik dan sistem pencahayaan pada ruang pergelaran.

a. Bentuk ruang

Bentuk ruang kipas dan bentuk panggung proscenium dianggap paling efektif untuk ruang pergelaran dalam ruang. Sedangkan untuk ruang pergelaran di luar ruangan bentuk panggung terbuka berbentuk kipas dengan panggung proscenium dianggap baik untuk digunakan.

b. Sistem akustik

Untuk mendapatkan kenyamanan audial dilakukan dapat dengan beberapa cara, yaitu bahan dan konstruksi ruang, sistem penguat bunyi, dan pengendalian bising.

c. Sistem pencahayaan

Pencahayaan panggung dibagi menjadi tiga jenis pencahayaan yaitu pencahayaan pada artis, pencahayaan umum dan pencahayaan background untuk memberikan efek. Sistem pencahayaan pada artis mengadopsi dari sistem blencong di pergelaran wayang. Di pergelaran wayang blencong menyoroti objek yaitu wayang.

d. Penyelesaian akustik pada area penonton

Lantai pada area penonton diselesaikan dengan lantai bertingkat yang dapat membantu meningkatkan kualitas penonton. Lantai yang bertingkat membuat distribusi suara lebih merata dan dapat menciptakan kenyamanan visual yang baik.

\subsection{Konsep Bentuk Masa}

Bentuk massa terbagi menjadi kepala, badan dan kaki. Bentuk atap yang berbeda akan dijadikan pembeda fungsi bangunan, seperti pada bangunan yang umum di Banyumas. Atap tajug dapat digunakan untuk mushola. Bentuk joglo digunakan untuk untuk pendhapa. Bentuk atap kampung dan pengolahannya digunakan untuk massa yang lain (lihat Gambar 5).

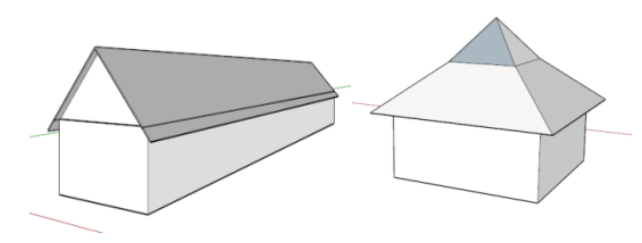

Gambar 5 Transformasi Bentuk

\subsection{Konsep Tata Masa}

Tata masa kawasan menggunakan komposisi terpusat. Pusat orientasi kawasan berupa ruang terbuka yang diwujudkan dengan taman dan sclupture di tengahnya. Taman digunakan sebagai komponen pengikat dari massa-massa di sekitarnya. Selain itu keberadaan taman sebagai ruang terbuka berguna mewadahi kebiasaan srawung atau suka berinteraksi di masyarakat. Tata massa mengikuti bentuk Kadipaten Banyumas yang menerapkan alun-alun, sapit urang, dan pendhapa di bagian depan (lihat Gambar $6)$. 


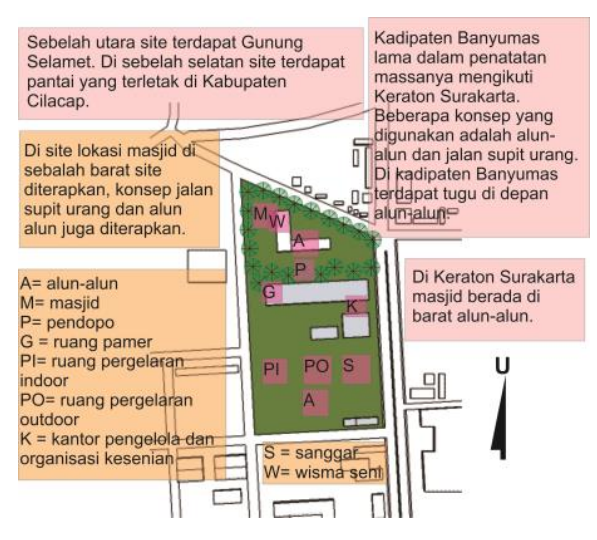

Gambar 6 Konsep Tata Masa

\subsection{Konsep Klimatololgis}

Tapak berada di iklim tropis dengan lama penyinaran matahari yang cukup. Pergerakan matahari dari timur ke barat memberikan pencahayaan langsung tanpa pembayangan di tapak. Cahaya matahari dimanfaatkan untuk penerangan ruangan. Pemanfaatan cahaya matahari dilakukan dengan adanya bukaan berupa jendela pada bangunan. Desain jendela yang umum digunakan masyarakat adalah jendela kayu dan kaca (lihat Gambar 7).
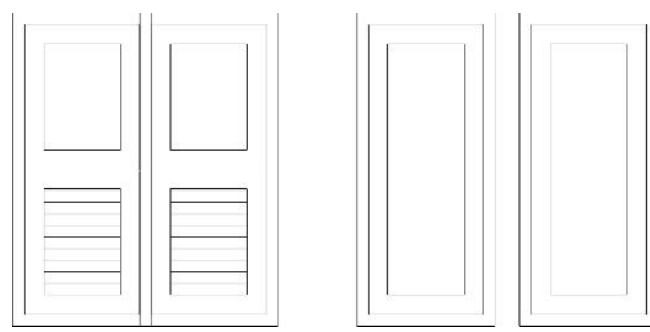

Gambar 7 Desain Jendela yang Sering Digunakan Masyarakat Sumber : Ismunandar:1993

Angin di tapak akan dimanfaatkan untuk menggerakan kitiran sebagai elemen yang menambah suasana pesisir pantai dan mendinginkan udara ruangan.

\subsection{Konsep Sirkuasi dalam Tapak}

Sirkulasi secara horizontal di Kadipaten Banyumas lama menggunakan sirkulasi memutar dan sirkulasi linear. Sedangkan sirkulasi secara vertikal menggunakan undhak-undhakan seperti pada rumah srotong (lihat Gambar 8).

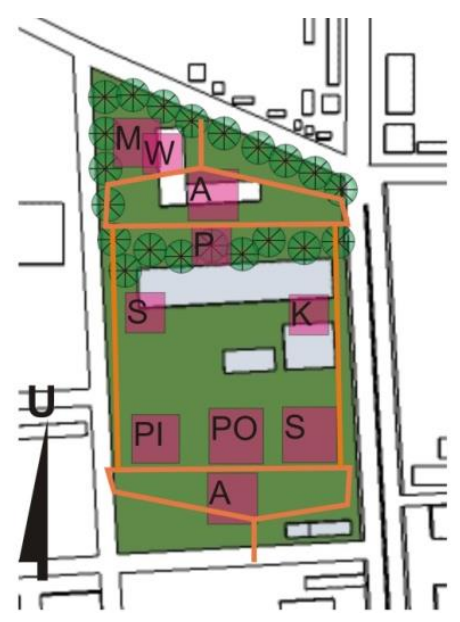

Gambar 8 Sirkulasi

\subsection{Konsep Tampilan Bangunan}

Bangunan akan ditampilkan dengan bentuk dasar kotak yang berasal dari bentuk dasar rumah srotong. Bentuk atap yang digunakan adalah bentuk atap joglo, tajug dan kampung. Material yang digunakan dalam Gedung Seni dan Budaya adalah yang mendukung tampilan bangunan. Beberapa material yang digunakan adalah batu bata ekspos, batu kali dan kerikil. Warna yang dipilih adalah warna alam yang dapat menampilkan kesan etnik seperti merah bata, coklat, abu-abu dan orange. Ragam hias yang digunakan adalah sulur-sulur dan daun bergelung (lihat Gambar 9).

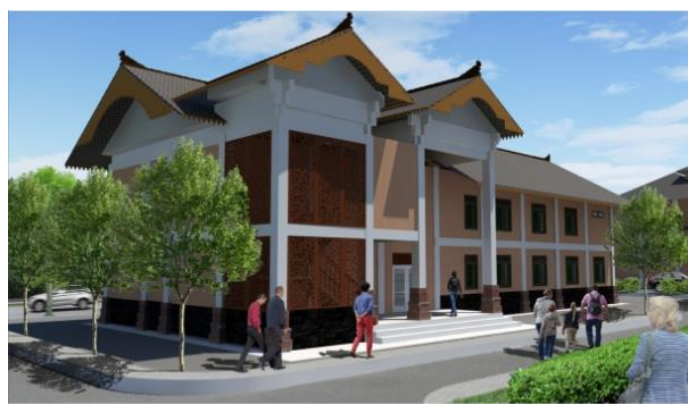

Gambar 9 Tampilan Bangunan Pengelola

\subsection{Konsep Interior}

Interior menggunakan pager gebyok untuk membatasi ruang-ruang tertentu. Cahaya lampu yang dipilih adalah cahaya lampu yang berwarna kuningan. Warna untuk ruang dalam menggunakan warna alam seperti coklat kayu dan batu bata. Ornamentasi yang digunakan berupa ragam hias yang digunakan pada elemen ruang (lihat Gambar 10). 


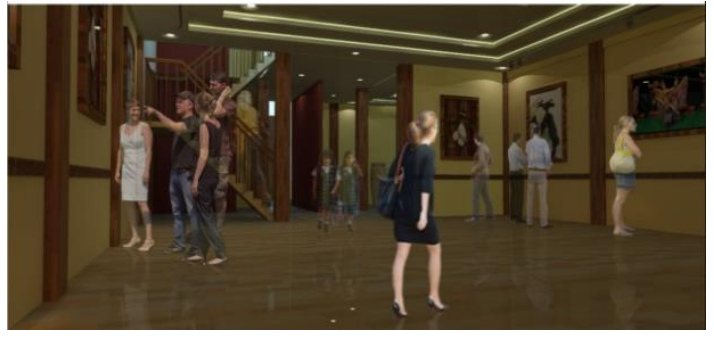

Gambar 10 Interior Ruang Galeri

\subsection{Konsep Pemilihan dan Pengolahan Material}

Material yang akan digunakan pada Gedung Seni dan Budaya Banyumas adalah material lokal. Material lokal yang dimaksud adalah material yang diproduksi oleh masyarakat Banyumas dan sekitanya. Beberapa material tersebut adalah genteng dari Pancasan Ajibarang atau Kebumen, batu kali dan pasir dari Sungai Serayu.

\subsection{Konsep Landscape}

Konsep landscape mempetimbangan elemen-elemen Landscape yang digunakan di kawasan Kadipaten Banyumas yang lama (lihat Gambar 11).

a. Softscape

Vegetasi berupa pohon tinggi pada kawasan di pertahankan keberadaannya. Satu pohon di timur laut akan dipertahankan dan diekspos untuk menunjukkan lokasi dari waktu ke waktu.

b. Hardscape

Hardscape berfungsi sebagai pendukung kegiatan seperti jalur pedestrian, jalur sirkulasi kendaraan, dan area parkir. Landcover aspal cocok digunakan untuk tempat sirkulasi kendaraan dan tempat parkir. Paving digunakan untuk area pedestrian bagi pengunjung yang berjalan kaki atau berjalan dari parkiran menuju gedung.

c. Landscape furniture

Landscape furniture merupakan elemen tambahan untuk mendukung kegiatan yang berjalan. Bentuk elemen furniture yang digunakan adalah penerangan, tugu, gapura, dan kitiran.

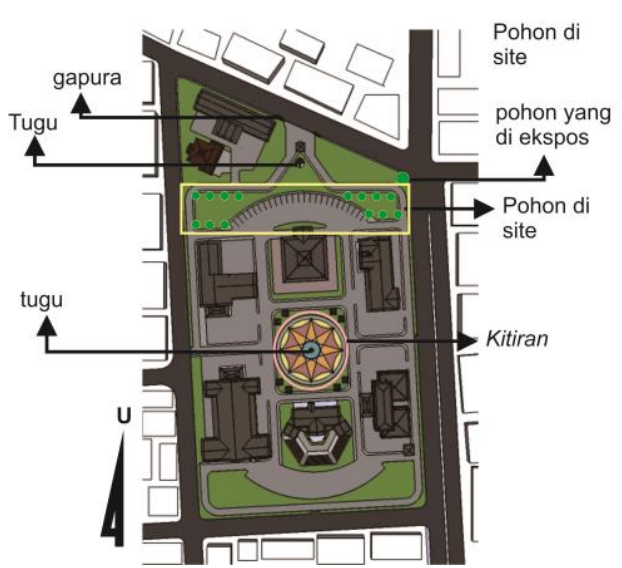

Gambar 11 Landscape

\subsection{Konsep Struktur}

Menggunakan sistem struktur rangka yang terbagi menjadi sub structure (struktur bawah), upper structure (struktur tengah) dan supper structure (struktur atas).

a. Sub Structure (struktur bawah)

Elemen-elemen sub structure yang akan digunakan adalah pondasi footplate, pondasi ini merupakan pondasi titik seperti umpak.

b. Super Structure

Super structure pada sistem rangka berupa kolom-kolom penyangga bangunan. Kolom ini berfungsi sebagai penyalur beban dari atap ke pondasi.

c. Upper Structure

Sub structure merupakan bagian atas bangunan yang berfungsi menyalurkan beban ke dalam tanah. Konstruksi yang digunakan adalah konstruksi kayu dan penutup atap berupa genting tanah liat.

\section{KESIMPULAN (KONSEP DESAIN)}

Konsep perencanaan dan perancangan Gedung Seni dan Budaya Banyumas mengunakan pendekatan atau sudut pandang filosofis lokalitas. Gedung ini direncanakan berada di Jalan S.Parman Purwokerto. Luasan lahan yang ada berkisar $23.000 \mathrm{~m} 2$ dengan kebutuhan luas bangunan $8.219 \mathrm{~m} 2$. Sisa lahan yang tidak digunakan akan dijadikan daerah pengembangan. Pendekatan lokalitas di objek ini terlihat di bentuk ruang, bentuk 
massa, tata massa, tampilan eksterior, desain interior, landscape, material bangunan, dan struktur.

Bentuk ruang galeri dan pergelaran di dalam ruang menggunakan bentuk kotak yang merupakan bentuk umum dari rumah srotong. Bentuk massa menggunakan bentuk atap joglo, tajug dan bentuk kampung yang dimodifikasi. Tata massa menerapkan alun-alun, jalan sapit urang dan pendhapa di bagian depan. Tampilan eksterior menggunakan pompok atau tutup keong, dan ragam hias sebagai ornamentasi. Interior akan didesain dengan mempertimbangkan furniture yang memberikan nuansa etnik, pencahayaan berwarna kuning dan ragam hias sebagai ornamentasi. Penataan landscape menggunakan elemen-elemen landscape yang biasa digunakan di kawasan di Banyumas, seperti tugu, gapura dan kitiran. Material yang digunakan berasal dari material produksi lokal seperti genteng dan batu bata di Kebumen.

\section{REFERENSI}

Ismunandar. 1993. Joglo Arsitektur Rumah Tradisional Jawa. Semarang : Dahara Prize.

Koderi, M. 1991. Banyumas wisata dan Budaya. Purwokerto : Metrojaya.

Koenjaraningrat. 1984. Kebudayaan Jawa. Jakarta : Balai pustaka. 